\title{
PARTISIPASI KARANG TARUNA TERHADAP KEGIATAN MASYARAKAT MELALUI AKSI SOSIAL
}

\author{
Nandang Rukanda ${ }^{1}$, Sri Nurhayati ${ }^{2}$, Ganda $^{3}$ \\ 1,2,3 Magister Pendidikan Masyarakat, IKIP Siliwangi \\ 11nandangsae@gmail.com
}

\begin{abstract}
Received: April, 2020; Accepted: Mei, 2020

This study raises the problem of the still low Youth Organization Participation Against Community Activities in Cikole Village, Lembang District, West West Bandung Regency. The objectives of the study are: (1) To find out the organized youth activities in Cikole Village, Lembang Subdistrict, West Bandung Regency (2) To find out the effectiveness of social actions carried out by Youth Organization (3) To find out the impact of social action by Youth Organization on community participation . This research uses descriptive research methods, data collection techniques using questionnaires, interviews, observations, and documentation studies. Research objects 50 people. The results of the research and findings show that: Youth activities with organized institutions color the lives of the people with various activities. The social action programs undertaken include (1) Collaborative Work to build villages and communities. (2) Greening the Environment. (3). Compensation for the poor, the poor and orphans. (4) Community Reading Gardens and (5) Houses for the Poor. There is a paradigm shift in thinking in people's lives by placing young people in strategic positions. The obstacle faced by Karang Taruna Cikole Village is the difficulty to synergize the various empowerments in an integrated program, funding constraints and misunderstanding among the members of the youth organization. The conclusion shows that social action carried out by Karang Taruna Cikole Village is seen as able to prosper the environment.
\end{abstract}

Keywords: Participation, Youth Organization, Social Action.

\begin{abstract}
Abstrak
Penelitian ini mengangkat permasalahan masih rendahnya Partisipasi Karang Taruna Terhadap Kegiatan Masyarakat di Desa Cikole Kecamatan Lembang Kabupaten Bandung Barat Barat. Tujuan penelitian adalah : (1) Untuk mengetahui kegiatan pamuda dengan wadah yang terorganisir di Desa Cikole Kecamatan Lembang Kabupaten Bandung Barat (2) Untuk mengetahui efektivitas aksi sosial yang dilakukan Karang Taruna (3) Untuk mengetahui dampak aksi sosial yang dilakukan Karang Taruna terhadap partisipasi masyarakat. Penelitian ini menggunakan metode penelitian deskriptif, teknik pengumpulan data menggunakan angket, wawancara, observasi, dan studi dokumentasi. Objek penelitian 50 orang. Hasil penelitian dan temuan menunjukkan bahwa: Kegiatan pemuda dengan wadah yang terorganisir mewarnai kehidupan masyarakat dengan berbagai aktivitasnya. Program aksi sosial yang dilakukan diantaranya adalah (1) Kerja Bakti Bersama membangun desa dan masyarakat. (2) Penghijauan Lingkungan. (3). Santunan terhadap masyarakat miskin, kaum duafa dan anak yatim. (4) Taman Bacaan Masyarakat dan (5) Bedah Rumah Warga Miskin. Terjadi perubahan paradigma berfikir dalam kehidupan masyarakat dengan menempatkan para pemuda pada posisi yang strategis. Kendala yang dihadapi Karang Taruna Desa Cikole adalah sulitnya untuk mensinergiskan berbagai pemberdayaan itu dalam suatu program yang terpadu, kendala pendanaan dan miss pemahaman diantara para anggota organisasi karang taruna. Kesimpulannya menunjukkan aksi sosial yang dilakukan Karang Taruna Desa Cikole dipandang dapat mensejahterakan lingkungannya.
\end{abstract}

Kata Kunci: Partisipasi, Karang taruna, Aksi sosial.

How to Cite: Rukanda, Nurhayati \& Ganda. (2020). Partisipasi Karang Taruna Terhadap Kegiatan Masyarakat Melalui Aksi Sosial. Comm-Edu (Community Education Journal) 3 (2), 144-155. 


\section{PENDAHULUAN}

Dalam rangka meningkatkan partisipasi karang taruna terutama generasi muda, perlu ditingkatkan kegiatan kepemudaan yang berdaya guna dan berhasil guna. Dalam hubungan ini pemerintah memang berniat sungguh-sungguh, terbukti dengan adanya kebijaksanaan kepemudaan yang terdapat dalam GBHN. Hal ini tentu mengingat jumlah yang cukup besar, seperti dikemukakan oleh Surakhmad, W., (1980 : 4) bahwa : "Pemuda merupakan lapisan eksponental bangsa yang sedikitnya berjumlah $30 \%$ dari jumlah seluruh penduduk Indonesia". Disamping itu pemuda ialah pewaris cita-cita dan sekaligus sebegai generasi penerus perjuangan bangsa yang menjadi tumpuan dan harapan di masa yang akan datang.. Karena itu mereka umumnya memiliki kepekaan-kepekaan terhadaap hal-hal baru yang terdapat pada lingkungannya yang dirasakan dapat menunjukan bahwa dirinya sebagai pribadi.

Kedudukan angkatan muda dalam suatu masyarakat adalah vital bagi masyarakat itu. Ketiadaan pembinaan dan kontrol terhadap nilai-nilai baru yang akan mempengaruhi pemuda, tidak mustahil akan muncul gejala sosial yang tidak diharapkan seperti tindak kejahatan atau kenakalan remaja. Pembinaan dan pengembangan generasi muda merupakan salah satu upaya pencegahan untuk menanggulangi permasalahan sosial dan sekaligus sebagai pengembangan sumber daya manusia melalui kegiatan organisasi.

Karang Taruna merupakan salah satu organisasi yang dapat mengambil prakarsa dalam menangani masalah pemuda, sebagaimana dikemukakan Hidayatullah F., (2010) bahwa "Karang taruna adalah suatu organisasi kepemudaan yang ada di Indonesia dan merupakan sebuah wadah atau tempat pengembangan jiwa sosial generasi muda". Dengan demikian Karang Taruna dapat mewadahi sekaligus mengarahkan apa yang dikehendaki generasi muda seseuai dengan misinya yang mengarah pada perubahan tingkah laku positif melalui berbagai kegiataan yang dilaksanakan.

Salah satu potensi yang ada di masyarakat dalam menunjang proses pembangunan adalah adanya partisipasi dan dedikasi yang tinggi dari para pemimpin dalam melaksanakan pekerjannya serta adanya pemuda yang sadar akan kedudukan dan peranannya sebagai generasi penerus. Berdasarkan pemikiran di atas, penulis merasa tertarik untuk meneliti Karang Taruna di Desa Cikole Kecamatan Lembang Kabupaten Bandung Barat. Program kegiatan yang dilaksanakan Karang Taruna beragam meliputi kegiatan sosial, kegiatan rekreatif, kegiatan edukatif, latihan keterampilan praktis serta bidang pengembangan sosial. Berangkat dari latar belakang di atas, dapat diidentifikasi masalah sebagai berikut: (1) Adanya ketidak sesuaian antara kebutuhan pemuda dengan program kegiatan yang dilaksanakan. (2) Belum efektifnya kegiatan pamuda dengan wadah yang terorganisir baik ditingkat RT dan RW. (3) Kurang kredibilitasnya pengurus dihadapan atau dimata para anggota Karang Taruna.

Adapun masalah penelitian dirumuskan sebagai berikut: (1) Bagaimana kegiatan pamuda dengan wadah yang terorganisir di Desa Cikole Kecamatan Lembang Kabupaten Bandung Barat? (2) Bagaimana efektivitas aksi sosial yang dilakukan Karang Taruna Desa Cikole Kecamatan Lembang Kabupaten Bandung Barat? (3) Bagaimana Dampak aksi sosial yang dilakukan Karang Taruna terhadap partisipasi masyarakat? Adapun yang menjadi tujuan penelitian adalah: (1) Untuk mengetahui kegiatan pamuda dengan wadah yang terorganisir di Desa Cikole Kecamatan Lembang Kabupaten Bandung Barat (2) Untuk mengetahui efektivitas aksi sosial yang dilakukan Karang Taruna Desa Cikole Kecamatan Lembang Kabupaten Bandung Barat (3) Untuk mengetahui dampak aksi sosial yang dilakukan Karang Taruna terhadap partisipasi masyarakat. 


\section{TINJAUAN PUSTAKA}

\section{A. Karang Taruna Sebagai Wadah Kegiatan Pendidikan Luar Sekolah 1. Pendidikan Luar Sekolah}

Pendidikan Luar Sekolah sendiri adalah suatu proses pendidikan/pembelajaran yang terjadi diluar pendidikan dan sistem pendidikan sekolah (formal). Didalamnya terjadi komunikasi yang teratur dan terarah, dimana seseorang memperoleh informasi, pengetahuan, pelatihan ataupun bimbingan sesuai dengan usia dan kebutuhan hidupnya dengan tujuan mengembangkan tingkat keterampilan, sikap-sikap dan nilai-nilai, dengan suatu susunan struktur waktu, tempat, sumber-sumber dan warga belajar yang beragam, fleksibel, akan tetapi tetap terarahkan.

Santoso S. Hamijoyo (1982 : 40) memberi batasan Pendidikan Luar Sekolah sebagai berikut : "Pendidikan Luar Sekolah adalah usaha yang terorganisir secara sistematis dan kontinu di luar sistem persekolahan, melalui hubungan sosial untuk membimbing individu, kelompok dan masyarakat agar memiliki sikap dan cita-cita sosiakl (yang positif) guna meningkatkan taraf hidup di bidang mateeril, sosial, dan mental dalam usaha mewujudkan kesejahteraan sosial”.

Fungsi pendidikan nonformal adalah

1. Sebagai substitusi pendidikan sekolah (formal), bermakna pendidikan luar sekolah sepenuhnya menggantikan pendidikan sekolah.

2. Sebagai komplemen pendidikan sekolah, dimana Pendidikan luar sekolah materinya melengkapi apa yang diperoleh di bangku sekolah.

3. Sebagai suplemen pendidikan sekolah. Hal ini mengandung pengertian, bahwa kegiatan pendidikan luar sekolah yang materinya memberikan tambahan terhadap materi yang dipelajari disekolah.

4. Sebagai jembatan memasuki dunia kerja.

5. Sebagai wahana untuk bertahan hidup dan mengembangkan kehidupan

Sasaran Pendidikan Luar Sekolah adalah mereka yang droup out serta mereka yang telah menyelesaikan pendidikan tetapi masih membutuhkan pengetahuan dan keterampilan tertentu guna meningkatkan taraf hidupnya. Hal ini berlaku baik bagi mereka yang tinggal di pedesaan maupun di kota. Menurut pendapat Santoso S. Hamijoyo (1982: 25) sasaran PLS adalah :

1. Semua anggota masyarakat yang tidak mendapatkan kesempatan untuk memperoleh pendidikan formal.

2. Semua angota masyarakat yang karena sesuatu hal tidak dapat menyelesaikan studi pada tingkat tertentu, golongan ini dikenal dengaan nama anak gagal sekolah yang droup out.

3. Anggota masyarakat yang meskipun telah menyelesaikan studi pada tingkat tertentu (formal) masih

\section{Karang Taruna}

Karang Taruna adalah organisasi kemasyarakatan untuk pelayanan kesejahteraan sosial berfungsi sebagai sarana atau wadah yang dapat menampung segala aaspirasi dan mengeendalikan setiap kegiatan para remaja yang tidak bernaung di bawah organisasi politik dan tidak menyuarakan serta tidak melakukan kegiatan politik apapaun. (Pedoman Kegiatan Karang Taruna Depsos). Karang Taruna merupakan organisasi kemasyarakatan yang tumbuh, dibina dan dikembangkan secara fungsional oleh Departemen Sosial untuk memberikan 
pelayanan kesejahteraan sosial kepada anak dan remaja atas dasar prinsip dan metoda pekerjaan sosial dalam rangka pembangunan anak dan remaja.

Di dalam memasuki alam kedewasaan, individu sering terlibat di dalam kegiatan-kegiatan yang sebenarnya mengarah ada proses pendidikan, walaupun kadang-kadang proses ini kurang disadari oleh individu masing-masing. Dalam hal ini organisasi Karang Taruna dapat dikatakan merupakan lembaga pendidikan yang bersifat non formal, mempunyai program yang beragam yang mempunyai manfaat bagi para anggotanya.

Organisasi pemuda seperti Karang Taruna ini, lebih menunjang terwujudnya asas pendidikan sepanjang hayat, yang memberikan kesempatan belajar setiap saat dan tidak terikat oleh batas usia. Karang Taruna mempunyai program yang fleksibel. Fleksibilitas ini ditandai dengan adanya program yang beragam. Kegiatan terarah yang beragam tesebut sesuai dengan kebutuhan, bakat, minat dari pemuda itu sendiri. Dalam hal ini terdapat proses belajar mengajar atau saling membelajarkan, dimana unsur pendidikan tersebut diarahkan untuk memenuhi kepentingan peserta didik dalam rangka pencapaian tujuan penyelenggaraan program.

\section{B. Aksi sosial Karang Taruna}

Aksi sosial merupakan kegiatan yang terkoordinasikan untuk mencapai tujuan perubahan kelembagaan dalam rangka memenuhi kebutuhan, memecahkan masalah, mengoreksi ketidakadilan atau meningkatkan kualitas hidup manusia. Terjadi atas inisiatif dari tenaga profesional dibidang kesejahteraan sosial, ekonomi, politik, agama, militer, orang-orang yang secara langsung terkena masalah. Menurut Rusli Ibrahim (2001 :12) "Perilaku sosial adalah suasana saling ketergantungan yang merupakan keharusan untuk menjamin keberadaan manusia sebagai bukti bahwa manusia dalam memenuhi kebutuhan hidup sebagai diri pribadi tidak dapat melakukannya sendiri melainkan memerlukan bantuan dari orang lain. Artinya bahwa kelangsungan hidup manusia berlangsung dalam suasana saling mendukung dalam kebersamaan. Untuk itu manusia dituntut mampu bekerja sama, saling menghormati, tidak menggangu hak orang lain, toleran dalam hidup bermasyarakat". Menurut Krech, Crutchfield dan Ballachey (1982: 4) "Perilaku sosial seseorang itu tampak dalam pola respon antar orang yang dinyatakan dengan hubungan timbal balik antar pribadi. Perilaku sosial juga identik dengan reaksi seseorang terhadap orang lain."

Kegiatan aksi sosial tentunya mambawa pengaruh terhadap kehidupan masyarakat sekitarnya khususnya para korban ketidakadilan maupu korban yang tertimpa bencana. Pengaruh yang paling menonjol dirasakan oleh orang yang tertimpa musibah dan menerima bantuan-bantuan. Dengan diberikan bentuan- bantuan tersebut sebagai contoh masyarakat yang tadinya hanya sanggup makan sekali sehari menjadi menjadi dua kali sehari dan layanan berobat gratis, dengan adanya posyandu lansia dan pengobatan gratis dan tidak dipungut biaya sedikitpun, sehingga medapatkan keringanan beban hidup, selain itu juga dapat memicu keakraban antar warga, misalnya, dalam jangka waktu tertentu masyarakat berkumpul untuk membahas kegiatan-kegiatan yang akan diadakan oleh masyarakat sekitar dan memecahkan persoalan bersama.

\section{Hakekat Partisipasi Karang Taruna dalam Pembangunan}

Istilah partisipasi menurut Koentjaraningrat (1984 : 79) seringkali disamakan dengan frekuensi tinggi turut sertanya rakyat pedesaan dalam aktivitas-aktivitas bersama. Jadi menurut beliau belum ada pengertian yang jelas mengenai konsep partisipasi rakyat dalam dalam pembangunan. Istilah lain dari partisipasi yang merupakan sinonim adalah keikutsertaan, 
keterlibatan dan peran serta. Mengenai definisi yang dikemukakan oleh berbagai ilmuwan atau lembaga belum terdapat satu kesepakatan, sedangkan teori-teori yang digunakan pada umumnya langsung menyangkut kepada aplikasinya.

Menurut Santoso S Hamijoyo (1982 : 40) mengemukakan bahwa partisipasi karang tarunaberarti ikut serta, yaitu mengikuti dan menyertai pemerintah karena kenyataannya pemerintahlah yang sampai dewasa ini merupakan perancang, penyelenggara dan pembayar utama pembangunan. Partisipasi adalah ikut serta dalam kegiatan pembangunan masyarakat yang harus dilaksanakan dengan penuh tanggung jawab demi tercapainya tujuan yang telah ditetapkan. Oleh karena itu partisipasi karang tarunamutlak harus ada dalam pembangunan dengan usahanya untuk mencipatakan kemakmuran dan kesejahteraan rakyat.

Dalam usaha-usaha membangkitkan partisipasi karang taruna tidak dilakukan oleh pemerintah saja, melainkan oleh tokoh-tokoh masyarakat dan badan-badan swasta. Partisipasi karang taruna merupakan partisipasi dari sejumlah individu yang berada dalam kelompok yang terorganisasikan. Bagi pemrakarsa atau komunikator menjaadi penting untuk menggerakan interest individu menjadi kepentingan yang bersifat umum, sehingga timbul suatu aksi kelompok, aksi massa dengan kepentingan yang sama dan untuk dicapai bersama (Santoso Sastropoetro, $1988: 18$ ).

Dikarenakan signifikansi dan keabadiannya, maka partisipasi sesungguhnya merupakan faktor terhadap mana si pimpinan melakukan berbagai cara dan usaha untuk menimba sumber kretivitas serta mengembangkan kekuatan kohesif guna melaksanakan kerja sama. Dengan demikian kalau diperlukan sesuatu perintah para anggota kelompok akan memberikan respon secara kooperatif, untuk mencapai cita-cita bersama.

Dari uraian tersebut dapat ditemukan suatu pengertian bahwa pengaruh komunikator menjadi penting untuk menyadarkan kemampuan yang dimiliki masyarakat serta kesanggupan yang perlu digali supaya usaha-usaha masyarakat tumbuh dalam pembangunan untuk terwujudnya partisipasi karang tarunadalam mensukseskan pembangunan.

\section{Kebutuhan Aktualisasi Diri}

\section{Teori-Teori Kebutuhan}

D. Sudjana (1996 : 13) merumuskan kebutuhan sebagai sesuatu yang harus dipenuhi. Ke dalam istilah "sesuatu" tersebut termasuk keinginan, kehendak, harapan, atau keadaan. Pengertian ini sejalan dengan rumusan yang dikemukakan Burton dan Nurill (1976) dalam D. Sudjana (1996 : 14) bahwa kebutuhan adalah perbedaan (disperancy) antara sesuatu kenyataan yang seharusnya ada dengan suatu kenyataan yang ada pada saat ini.

Pentingnya kebutuhan dalam penyusunan dan pengembangan program Pendidikan Luar Sekolah didasarkan atas empat alasan. Pertama, kebutuhan adalah bagian penting dari keehidupan manusia. Kedua, keberhasilan manusia dalam kehidupan banyak dipengaruhi oleh tingkat kemampuannya dalam memenuhi kebutuhan. Ketiga, manusia melakukan upaya secara berlanjut dalam memenuhi kebutuhan itu. Keempaat, dalam suatu kebutuhan seseorang terdapat kebutuhan lain yang harus dipenuhi. Pendidikan luar sekolah akan memperoleh dukungan peserta didik apabila program-programnya disusun berdasarkan kebutuhan mereka sekaligus dapat meningkatkan motivasi mereka. Dengan kata lain, peserta didik akan tanggap dan berpartisipasi aktif dalam suatu kegiatan, bila program berorientasi pada upaya untuk memenuhi kebutuhan mereka. 


\section{b. Kelompok Sebagai Sarana Penentuan Kebutuhan}

Secara kodrati manusia tak mungkin hidup sendiri. Betapa pentingnya kehidupan bersama dalam kelompok untuk memenuhi kebutuhannya, kebutuhan untuk melangsungkan kehidupannya, kebutuhan untuk mempertahankan diri dari ancaman terhadap kehidupannya, bahkan kebutuhan untuk membina keturunannya sebagai penerus kehidupannya. Demikianlah sejak dahulu kala hingga sekarang dan samai masa mendatang. Akibat dari kemajuan dan perkembangan teknologi dari masa kemasa semakin tampak betapa sulitnya manusia dalam upayanya dalam memenuhi kebutuhannya, akan tetapi, disadarinya bahwa bagaimanapun kebutuhan hidupnya akan lebih mudah terpenuhi apabila ia mengusahakannya bersama orang lain daripada melakukannya sendiri. Maka masuklah ia kedalam suatu kelompok yang dalam waktu sekarang ini dinamakan organisasi.

\section{METODE}

\section{A. Desain Penelitian}

Pendekatan yang dilakukan dalam penelitian ini yaitu pendekatan kuantitatif. Hal ini dikarenakan penelitian ini untuk mengungkap fenomena sosial kemasyarakatan yang tidak mengedepankan angka-angka, tetapi berkenaan dengan motivasi dan prilaku kemanusiaan yang ukurannya kualitas kedalaman kajian. Menurut Moleong (2005:6), penelitian kualitatif adalah penelitian yang bermaksud untuk memahami fenomena tentang apa yang dialami oleh subjek penelitian misalnya perilaku, persepsi, motivasi, tindakan, dll secara holistic, dan dengan cara deskripsi dalam bentuk kata-kata dan bahasa, pada suatu konteks khusus yang alamiah dan dengan memanfaatkan berbagai metode alamiah. Anggapan yang mendasari penelitian ini adalah bahwa motivasi berpengaruh terhadap prilaku kewirausahaan seseorang oleh karena itu maka disusun rancangan penelitian yang akan mengungkap fenomena soaial secara mendalam dan menyeluruh dengan rancangan penelitian memeri peluang berkembang selama proses penelitian berlangsung.

\section{B. Populasi dan Sampel Penelitian \\ 1. Populasi}

Populasi adalah wilayah generalisasi yang terdiri atas; objek/subjek yang mempunyai kuantitas dan karakteristik tertentu yang ditetapkan dan kemudian ditarik kesimpulannya. Jadi populasi bukan hanya orang, tetapi juga benda-benda alam yang lain. Populasi juga bukan sekedar jumlah yang ada pada objek/subjek yang dipelajari, tetapi meliputi seluruh karakteristik/sifat yang dimiliki oleh subjek atau objek itu (Sugiyono, 1999 : 57). Populasi adalah sekelompok subjek yang akan menjadi sumber data baik berupa benda, manusia, gejala maupun peristiwa sesuai dengan pokok permasalahan yang diteliti. Definisi lain yang dianggap lebih sederhana, dikemukakan oleh Suharsimi Arikunto (1987 : 102), yaitu populasi merupakan keseluruhan objek yang diteliti. Dalam penelitian ini penulis mengambil populasi diambil dari seluruh anggota karang taruna Desa Cikole Kecamatan Lembang Kabupaten Bandung Barat yang berjumlah sebanyak 200 orang.

\section{Sampel}

Sampel merupakan bagian atau perwakilan dari populasi yang memiliki karakteristik yang sama dan dapat mewakili populasi. Para ahli tidak memberikan kepastian, berapa besar sampel yang harus diambil dari sebuah penelitian. Namun pada umumnya pada ahli memberikan perkiraan sebagai pedoman dalam menentukan besarnya sampel dari sebuah populasi. Sampel adalah bagian populasi yang dapat dianggap mewakili populasi yang bersangkutan dan diambil dari keseluruhan sifat-sifat atau generalisasi yang ada pada populasi (Sumaatmadja, 1988). Menurut Sugiyono (2004:137) adalah bagian dari jumlah dan karakteristik yang dimiliki oleh 
Melalui Aksi Sosial

populasi. Sedangkan menurut Masri Singarimbun (2008 : 106) yang dimaksud dengan sampel adalah: "besarnya sampel tidak boleh kurang dari $10 \%$ populasi". Berlandaskan pada konsep diatas, pada penelitian ini penulis mengambil sampel sebanyak $25 \%$ dari seluruh anggota Karang Taruna Desa Cikole yaitu berjumlah 50 orang.

\section{Prosedur Penelitian}

Langkah-langkah atau prosedur yang dilakukan dalam penelitian ini adalah sebagai berikut.

1. Perencanaan

Dalam Perencanaan ini peneliti melakukan penyusunan alat pengumpul data terlebih dahulu berupa kisi-kisi secara sistematis sesuai dengan masalah atau pertanyaan penelitian. Adapun kegiatan dalam penyusunan alat pengumpul data adalah sebagai berikut :

a. Merumuskan problematika penelitian dengan variabel dan indikator-indikator yang akan dijadikan pertanyaan penelitian.

b. Menyusun pertanyaan-pertanyaan atau pernyataan beserta alternatif jawabannya yang disesuaikan dengan problematika penelitian dan disertai petunjuk-petunjuk pengisian sehingga akan jelas maksud dan tujuannya oleh responden.

\section{Tindakan}

Responden dibagi peran oleh peneliti, kemudian peneliti memberikan perlakuan dengan observasi dan wawancara untuk mengungkap pendapat dan keadaan yang sebenarnya.

1. Menganalisis data.

2. Merumuskan hasil studi.

3. Menyusun rekomendasi untuk pembuatan keputusan.

\section{Teknik Pengumpulan Data}

Suatu penelitian memerlukan data atau informasi yang berguna untuk bahan pemecahan masalah yang ditemukan dalam penelitian tersebut. Untuk itu diperlukan teknik pengumpulan data yang tepat, agar penelitian mencapai tujuan yang diinginkan.

Adapun teknik yang dipergunakan untuk mengumpulkan data dalam penelitian ini yaitu :

a. Wawancara, yaitu penulis lakukan untuk mendapatkan data sebagai jawaban dari pertanyaan-pertanyaan penelitian itu sendiri.

Sehubungan dengan teknik wawancara ini H. Engking S. Hasan (1997 : 49-50), menyatakan bahwa : "Wawancara adalah sebagai proses interaksi, interelasi, mempunyai karakteristik, isyarat dan persepsi dan didalam prosesnya perlu diperhatikan beberapa hal yaitu situasi wawancara, isi wawancara, pewawancara/ interviewer, dan interviewee."

b. Observasi, yaitu mengadakan peninjauan langsung terhadap objek penelitian yang dalam hal ini terdiri atas gambaran daerah lokasi penelitian, serta kegiatan proses penyuluhan.

Hal ini sejalan dengan pendapat yang dikemukakan oleh Suharsimi Arikunto (1983 : 111), bahwa observasi itu meliputi kegiatan pemusatan perhatian terhadap sesuatu obyek dengan menggunakan seluruh alat indera. Jadi observasi dapat dilakukan melalui penglihatan, penciuman, pendengaran, peraba dan pengecap. Apa yang dikatakan ini sebenarnya adalah pengalaman langsung.

c. Angket, yaitu untuk mengumpulkan data melalui serangkaian pertanyaan tertulis yang disusun dan disebarkan untuk mendapatkan informasi atau keterangan responden mengenai masalah yang sedang diteliti.

Angket adalah daftar pertanyaan tertulis yang digunakan untuk memperoleh keterangan tertentu dari responden yang kadang-kadang tersebar tempat tinggalnya. Dalam penyusunan angket ini dapat bersifat tertutup, terbuka juga dapat pula dengan kombinasi antara penutup dan terbuka. 
d. Studi Literatur, yaitu penulis gunakan sebagai bahan penunjang pada uraian teoritis yang sekiranya ada hubungannya dengan penyuluhan, juga sebagai teknik pembantu dalam pengumpulan data.

\section{E. Analisis Data}

Analisis data dilakukan secara induktif, yaitu penelitian dilakukan dengan tidak dimulai dari deduksi teori tetapi dimulai dari fakta empiris. Peneliti terjun ke lapangan, mempelajari, menganalisis, menafsirkan dan menarik kesimpulan dari fenomena yang ada di lapangan. Peneliti dihadapkan kepada data yang diperoleh dari lapangan. Dari data tersebut, peneliti menganalisis sehingga menemukan makna yang kemudian makna itulah menjadi hasil penelitian. Analisis kualitatif dilakukan sepanjang penelitian dari awal hingga akhir. Hal ini dilakukan karena, peneliti kualitatif mendapat data yang membutuhkan analisis sejak awal penelitian. Bahkan hasil analisis awal akan menentukan proses penelitian selanjutnya.

\section{HASIL DAN PEMBAHASAN}

\section{Hasil}

\section{A. Gambaran Objek Penelitian}

1. Letak Geografis

Desa Cikole merupakan salah satu desa yang berada di wilayah Kecamatan Lembang Kabupaten Bandung Barat dengan luas 1.465,56 Ha, jarak dari desa ke ibukota kecamatan 3,5 $\mathrm{km}$, ke ibukota kabupaten $20 \mathrm{~km}$ dan ke ibukota provinsi $35 \mathrm{~km}$. wilayah Desa Cikole merupakan daratan dengan ketinggian $11.280 \mathrm{~km}$ di atas permukaan laut, curah hujan 2.207 $\mathrm{mm} /$ tahun, dan suhu rata-rata berkisar $20^{\circ} \mathrm{C}$.

Tabel 1. Jenis dan Klasifikasi Tanah Di Desa Cikole

\begin{tabular}{|l|l|l|}
\hline No & Penggunaan Tanah & Luas Tanah/Ha \\
\hline 1 & Tanah daratan dan sawah & 918,10000 \\
2 & Pemukiman umum & 536,73565 \\
3 & Tanah pemerintah desa & - \\
4 & Sekolah & 0,20000 \\
5 & Pasar & - \\
6 & Tempat peribadatan & 0,75000 \\
7 & Kuburan dan jalan & 0,02850 \\
8 & Lain-lain & 0,77150 \\
\hline Jumlah & $\mathbf{1 . 4 5 6 , 5 6 0 0 0}$ \\
\hline
\end{tabular}

Sumber : Monografi Desa Cikole 


\section{Keadaan Penduduk}

Berdasarkan catatan yang terdapat di Desa Cikole Kecamatan Lembang Kabupaten Bandung Barat jumlah penduduk seluruhnya adalah 7092 orang, yang terdiri dari 3499 orang perempuan, dan 3594 orang laki-laki. Menurut Tingkat Pendidikan di Desa Cikole Kecamatan Lembang Kabupaten Bandung Barat tersaji pada tabel 4 di bawah ini:

Tabel 2. Keadaan Penduduk Menurut Tingkat Pendidikan

\begin{tabular}{|c|l|c|}
\hline No & \multicolumn{1}{|c|}{ Jenis } & $\mathrm{f}$ \\
\hline 1 & Belum tamat & 4500 \\
2 & SD/sederajat & 1765 \\
3 & Tamat SD/sederajat & 1869 \\
4 & Tamat SLTP/sederajat & 1765 \\
5 & Tamat SLTA/sederajat & 855 \\
& Tamat Perguruan & \\
& Tinggi & 1.078 \\
\hline \multicolumn{2}{|l}{ Jumlah } & \\
\hline
\end{tabular}

Sumber : Profil Desa Cikole Tahun 2010

B. Kegiatan Karang Taruna Desa Cikole Kecamatan Lembang Kabupaten Bandung Barat Taruna Desa Cikole dijadikan awal dari usaha para pemuda dalam mensejahterakan sosial lingkungannya dan dituangkan dalam kepedulian yang ditorehkan pada berbagai macam kegiatan. Tim PKK, Kepala Desa dan Karang Taruna bekerja sama membuat program kegiatan yaitu:

1. Kerja Bakti Bersama Masyarakat

Kerja bakti dilakukannya dalam rangka pemeliharaan lingkungan, fasilitas atau sarana umum, juga secara swadaya oleh masyarakat setempat, misalnya secara gorong-gorong membersihkan lingkungan tempat tinggal, atau memperbaiki jalan yang rusak secara bersama-sama tanpa pamrih. Kegiatan kerja bakti dilakukan biasanya setiap satu bulan sekali, atau pada saat jika masyarakat ada yang membutuhkan bantuan, semua karang taruna ikut membantu. Kekompakan dan kekomitmen dalam menjalankan aktifitas itu dijalaninya secara kompak dan kompak bersama-sama. Mereka bergerak secara gotong royong demi kepentingan bersama mencapai hasil yang lebih baik. Semua anggota karang taruna harus melakukan bersih lingkungan secara bersama-sama.

\section{Penghijauan Lingkungan}

Program penghijaun sendiri dipandang pentingoleh Karang Taruna Desa Cikole dilihat dari beberpa manfaatnya seperti: (1) Peran penghijauan dapat dikatakan sebagai organ pernafasan vital dari lingkungan. Jika pada manusia adalah paru-paru yang mempunyai sebagai alat pernafasan. Jika pada lingkungan penghijauan merupakan paru-paru lingkungan. (2) Penghijauan dapat berguna sebagai pengatur lingkungan, mengatur produksi udara yang akan dihasilkan. Hasil udara sejuk, segar dan bersih sangat diatur oleh pengaruh dari penghijauan. (3) Penghijauan berperan bagi keseimbangan dari sebuah lingkungan alam dan sumber daya alam. (4) Dengan proses penghijauan akan menimbulkan keindahan dan kebersihan yang membuat manusia dan ekosistem yang lain dapat hidup dengan jangka waktu yang lebih lama. 


\section{Santunan terhadap Kaum Duafa.}

Karang Taruna Desa Cikole sering pula menyelenggarakan kegiatan bakti sosial kepada Kaum dhuafa, anak-anak yatim piatu maupun kepada fakir miskin dan orang orang yang tidak mampu dengan berikan sembako. Dalam rangka mencari solusi dalam permasalahan sosial yang diadapi oleh masyarakat, karang taruna Desa Cikole mampu mengabdikan dirinya kepada masyarakat menunjukan kepedulian terhadap masyarakat yang kurang mampu. Kegiatan ini bertujuan untuk meringankan kehidupan mereka yang kekurangan. Adanya program tersebut tidak terlepas dari partisipasi karang tarunayang ikut membantu sesuai dengan prioritas dan juga sesuai dengan kemampuan mereka untuk memberikan sumbangan masyarakat yang kekurangan.

\section{Taman Bacaan Masyarakat}

Taman Bacaan Masyarakat dibangun Karang Taruna Desa Cikole setempat dengan menggunakan lahan milik warga. Tujuan dibangunnya yaitu untuk meningkatkan interaksi sosial masyarakat serta memberikan bimbingan belajar bagi anak-anak. Adanya taman bacaan diharapkan menjadi tempat pelatihan berbagai keterampilan serta menjadi titik kumpul warga dari semua lapisan.

\section{Bedah Rumah Warga Miskin.}

Program Bedah Rumah ini merupakan salah satu upaya untuk mempercepat penanggulangan kemiskinan di Desa Cikole yang bertujuan agar keluarga miskin memliki rumah yang layak huni dan dapat memenuhi kebutuhan dasarnya secara minimal. Program ini diprioritaskan bagi masyarakat yang memenuhi kriteria antara lain adalah status ekonominya rendah serta rumahnya tidak layak huni.

\section{Pembahasan}

\section{A. Efektivitas Aksi Sosial yang Dilakukan Karang Taruna Desa Cikole Kecamatan Lembang Kabupaten Bandung Barat.}

Dilihat dari beberapa kegiatan yang dilakukan karang taruna Desa Cikole sendiri, secara umum bisa dikatakan efektif dikarenakan telah berhasil menjadi solusi beberapa masalah sosial yang ada dimasyarakat. Hal ini dapat dilihat dari indikator efektivitas program kegiatan kerja dalam pelaksanaannya masyarakat sepertihalnya Kerja Bakti Bersama Masyarakat, penghijauan lingkungan, santunan terhadap kaum dhuafa, taman bacaan masyarakat dan bedah rumah masyarakat miskin. Tingkat efektivitas juga dapat diukur dengan membandingkan antara rencana yang telah ditentukan dengan hasil nyata yang telah diwujudkan, hal ini berhasil ditunjukan oleh kegiatan social karang taruna Desa Cikole Kecamatan Lembang Kabupaten Bandung Barat. Sudjana, N., (2008: 34-38), menyimpulkan bahwa efektivitas pelatihan sangat berhubungan dengan keberhasilan pengajaran, dan indikatornya dapat ditinjau berdasarkan dua keberhasilan kriteria yaitu kriteria keberhasilan dari segi proses dan keberhasilan dari segi proses, dan hal ini telah ditunjukan dalam kegiatan-kegiatan karang taruna Desa Cikole dan hasil yang terwujud baik secara fisik infrastuktur masyarakat maupun kepribadiannya.

\section{B. Dampak Aksi Sosial yang Dilakukan Karang Taruna terhadap Kegiatan Masyarakat}

Dampak aksi sosial yang dilakukan Karang Taruna terhadap partisipasi karang taruna dapat dikemukakan sebagai berikut: (1) Meningkatkan partisipasi aktif masyarakat dalam bekerja sama, gotong royong untuk mewujudkan tujuan dan kepentingan bersama, semisal kebersihan lingkungan, kelestarian alam, dan keamanan wilayah setempat melalui kegiatan Kerja Bakti Bersama Masyarakat dan penghijauan lingkungan, (2) Meningkatkan kepedulian social terhadap sesama masyarakat, dengan sikap saling membantu, saling menyantuni, sikap 
toleransi, kebersamaan melalui bantuan terhadap kaum dhuafa dan (4) dan bedah rumah masyarakat miskin. (3) Upaya peningkatan pengetahuan masyarakat dengan program pengadaan taman bacaan masyarakat, sehingga menjadikan mereka meningkat daya baca, tulis dan hitung dan pengetahuan literasinya.

Pemberdayaan masyarakat juga merupakan proses siklus terus-menerus, proses partisipatif di mana anggota masyarakat bekerja sama dalam kelompok formal maupun informal untuk berbagi pengetahuan dan pengalaman serta berusaha mencapai tujuan bersama pemberdayaan merupakan proses belajar dalam rangka pemberdayaan masyarakat akan berlangsung bertahap. Dari proses pemberdayaan tersebut kita mampu melihat mana yang harus diberdayakan seperti mampu menekankan bahwa dari proses pemberdayaan tersebut orang memperoleh keterampilan, pengetahuan, dan kekuasaan yang cukup mempengaruhi kehidupannya. Contohnya seperti adanya kegiatan karang taruna dalam kegitan bedah rumah yang sangat bermanfaat bagi masyarakat yang kurang mampu. Dari proses pemberdayaan inilah yang menjadi simbol tersendiri bagi Karang Taruna Desa Cikole sebagai pemberdaya masyarakat.

Kendala yang dihadapi Karang Taruna Desa Cikole dalam melakukan pemberdayaan masyarakat adalah sulitnya untuk mensinergiskan berbagai pemberdayaan itu dalam suatu program yang terpadu. Pemberdayaan masyarakat melalui aksi sosial bukanlah program yang dapat dilaksanakan dalam jangka waktu singkat tetapi musti dilakukan melalui berbagai tahapan atau proses yang harus benar-benar matang. Pemberdayaan harus dilaksanakan secara berkesinambungan dengan terus mengembangkan jenis-jenis kegiatan yang tepat untuk masyarakat. Meskipun mengenai program pemberdayaan banyak mengalami kelemahankelemahan yang terjadi dalam pelaksanaan program atau kegiatan dan ketidak berhasilan sasaran untuk mencapai tujuan namun harus diakui juga bahwa ada banyak program pemberdayaan aksi sosial yang berhasil dan mencapai tujuan yang ditetapkan.

Beberapa hal lain yang menjadi kendala Karang Taruna Desa Cikole dalam melakukan program pemberdayaan masyarakat melalui aksi sosial diantaranya adalah kendala dana. Seringkali kegiatan mereka tidak sinergi dengan kecukupan dana yang dibutuhkan sehingga dirasakan aktivitas aksi sosialnya tidak maksimal, karenanya dibutuhkan dukungan dari berbagai kalangan untuk mensupport program Karang Taruna baik dari unsur swasta maupun dari unsur pemerintah. Selain itu, sering terjadi miss pemahaman diantara para anggota organisasi Karang Taruna. Kebijakan memutuskan suatu masalah sering terjadi kesulitan dan melalui diskusi yang panjang karena harus melnyamakan persepsi yang berbeda dari internal anggota Karang Tarunayang terpengaruh kepentingan masing-masing.

\section{KESIMPULAN}

Berdasarkan hasil penelitian yang penulis lakukan maka dapat disimpulkan bahwa:

1. Efektivitas aksi sosial yang dilakukan Karang Taruna Desa Cikole Kecamatan Lembang Kabupaten Bandung Barat.

Karang Taruna Desa Cikole berjalan efektif dimasyarakat karena telah berhasil menjadi solusi berbagai masalah sosial yang ada dimasyarakat yang ditunjukan dengan berbagai kegiatan sosial yang dilakukan yaitu kerja bakti bersama masyarakat, penghijauan lingkungan, santunan terhadap kaum dhuafa, taman bacaan masyarakat dan bedah rumah masyarakat miskin. 
2. Dampak aksi sosial yang dilakukan Karang Taruna terhadap partisipasi masyarakat.

Terjadi perubahan paradigma berfikir dalam kehidupan masyarakat dengan menposisikan para pemuda pada posisi yang strategis. Masyarakat merasa dibantu dalam perubahan peningkatan pengetahuan, keterampilan dan sikap kebersamaan, meningkatkan etos kerja, rasa tanggung jawab, berani mengambil resiko dan gotong royong. Dampak aksi sosial terhadap partisipasi karang taruna adalah (1) Meningkatkan partisipasi aktif masyarakat dalam bekerja sama, gotong royong untuk mewujudkan tujuan dan kepentingan bersama. (2) Meningkatkan kepedulian sosial terhadap sesama masyarakat (3) Bedah rumah masyarakat miskin. (3) Pengadaan taman bacaan masyarakat,

\section{DAFTAR PUSTAKA}

Arikunto, Suharsimi, (2005), Manajemen Penelitian, Jakarta: Rineka Cipta

Depdiknas RI, (2005), Kamus Besar Bahasa Indonesia, Edisi ketiga, Balai Pustaka, Jakarta , (2003), Undang-Undang RI No. 20 Tahun 3003 tentang Sistem Pendidikan Nasional, Jakarta.

Hasan, Engking Soewarman, (1997), Strategi Menciptakan Manusia yang Bersumber Daya Unggul, Jurusan PLS, FIP, UPI, Bandung

Hidayatullah, Furqon., (2010), Pendidikan Karakter: Membangun Peradaban Bangsa. Surakarta. Yuma Pustaka.

Ibrahim, Rusli. (2001). Promosi Kesehatan Dengan Pendekatan Teori Prilaku, Media, Dan Aplikasinya. Semarang: PT. Raja Grafindo Persada.

Krech, Crutchfield dan Ballachey (1982), Individual in Society, Published by McGraw Hill

Koentjaraningrat. (2009) Manusia dan Kebudayaan di Indonesia. Djambangan. Jakarta.

Moleong, Lexy J. (2005), Metodologi Penelitian Kalitatif, Bandung: Rosda

Hamijoyo, S. (1982), Pengertian Falsafah dan Azas Pendidikan Non Formal, Bandung, PLS.

Sastropoetro, Santoso. (1988), Partisipasi, Komunikasi, Persuasi, dan Disiplin dalam Pembangunan Nasional, Bandung: Alumni.

Singarimbun, Masri dan Sofian Effendi. (2008), Metode Penelitian Survei, Jakarta: LP3ES.

Sudjana. (1996), Pendidikan Luar Sekolah Wawasan, Sejarah Perkembangan, Falsafah dan Faktor Pendukung, Bandung, Nusantara Press.

(1996), Strategi Pembelajaran dalam Pendidikan Luar Sekolah, Bandung, Nusantara Press.

Sugiyono. (2004). Memahami Penelitian Kualitatif. Bandung: Alfabeta

Surakhmad, Winarno. (1980). Psikologi Pemuda. Bandung: Jemmars.

Peraturan Menteri Dalam Negeri Republik Indonesia Nomor 5 Tahun 2007 Tentang Pedoman Penataan Lembaga Kemasyarakatan.

Peraturan Menteri Sosial Republik Indonesia Nomor 83 Tahun 2005 Tentang Pedoman Karang Taruna. 